\title{
APPLICABILITY OF THE COBB ANGLE MEASUREMENT IN IDIOPATHIC SCOLIOSIS USING SCANNED IMAGING
}

\author{
APLICABILIDADE DA MEDIDA DO ÂNGULO DE COBB NA ESCOLIOSE IDIOPÁTICA USANDO \\ IMAGEM DIGITALIZADA
}

\section{APLICABILIDAD DE LA MEDICIÓN DEL ÁNGULO DE COBB EN LA ESCOLIOSIS IDIOPÁTICA USANDO IMAGEN DIGITALIZADA}

\author{
Erasmo de Abreu Zardo ${ }^{1}$, Marcus Sofia Ziegler ${ }^{1}$, Afrane Serdeira1 ${ }^{1}$, Carlos Marcelo Donazar Severo ${ }^{3}$ Rodrigo Valente Frast ${ }^{1}$, Paulo Renato Rech² \\ lauro Toffolo ${ }^{1}$, Renata Sicliani Scalco ${ }^{3}$, Carla Helena Augustin Schwanke ${ }^{4}$ \\ 1. Pontifícia Universidade Católica do Rio Grande do Sul (PUCRS), Hospital São Lucas da PUCRS, Spine Group, Porto Alegre, RS, Brazil. \\ 2. Hospital Life Center, Spine Surgery, Belo Horizonte, MG, Brazil. \\ 3. University College London Institute of Neurology, Center for Neuromuscular Diseases and Division of Neuropathology, Queen Square London, United Kingdom. \\ 4. Pontifícia Universidade Católica do Rio Grande do Sul, Medical School, Institute of Geriatrics and Gerontology, Porto Alegre, RS, Brazil.
}

\begin{abstract}
Objectives: To compare the measurement of the Cobb angle on printed radiographs and on scanned radiographs viewed through the software "PixViewer". Methods: Preoperative radiographs of 23 patients were evaluated on printed films and through the software "PixViewer". The same evaluator, a spine surgeon, chose the proximal and distal limiting vertebrae of the main curve on printed radiographs, without identification of patients, and measured the Cobb angle based on these parameters. The same parameters and measurements were applied to scanned radiographs. The measurements were compared, as well as the choice of limiting vertebrae. Results: The average variation of the Cobb angle between methods was $1.48 \pm 1.73^{\circ}$. The intraclass correlation coefficient (ICC) was 0.99, demonstrating excellent reproducibility. Conclusion: The Cobb method can be used to evaluate scoliosis through the "PixViewer" tool with the same reliability as the classic method on printed radiographs.
\end{abstract}

Keywords: Scoliosis; Spinal diseases; Spinal curvatures; Radiographic image enhancement.

\section{RESUMO}

Objetivo: Comparar a aferição do ângulo de Cobb em radiografias impressas e em radiografias digitalizadas, visualizadas por meio da ferramenta "PixViewer". Métodos: Foram avaliadas as radiografias pré-operatórias de 23 pacientes em filmes impressos e pelo software "PixViewer". O mesmo avaliador, cirurgião de coluna, elegeu as vértebras limites proximal e distal da curva principal nas radiografias impressas, sem identificação dos pacientes, e realizou a aferição do ângulo de Cobb baseado nesses parâmetros. Os mesmos parâmetros e aferições foram aplicados às radiografias digitalizadas. As aferições foram comparadas, assim como a escolha das vértebras limites. Resultados: A variação média do ângulo de Cobb entre os métodos foi de 1,48 $\pm 1,73^{\circ}$. O coeficiente de correlação intraclasse (CCI) foi de 0,99, demonstrando replicabilidade excelente. Conclusão: O método de Cobb pode ser utilizado para avaliação da escoliose por meio da ferramenta "PixViewer" com a mesma confiabilidade que pelo método clássico em radiografias impressas.

Descritores: Escoliose; Doenças da coluna vertebral; Curvatura da coluna vertebral; Intensificação de imagem radiográfica.

\section{RESUMEN}

Objetivo: Comparar la medición del ángulo de Cobb en radiografías impresas y en radiografías digitalizadas vistas a través de la herramienta "PixViewer". Métodos: Se evaluaron las radiografías preoperatorias de 23 pacientes en películas impresas y a través del software "PixViewer". El mismo evaluador, cirujano de columna, eligió las vértebras proximal y distal límites de la curva principal en las radiografías impresas, sin identificación de los pacientes, y realizó la medición del ángulo de Cobb en base a estos parámetros. Los mismos parámetros y mediciones se aplicaron a las radiografías digitalizadas. Las mediciones fueron comparadas, así como la elección de las vértebras límites. Resultados: La variación promedio del ángulo de Cobb entre los métodos fue de 1,48 $\pm 1,73^{\circ}$. El coeficiente de correlación intraclase (CCI) fue de 0,99, demostrando reproducibilidad excelente. Conclusión: El método de Cobb puede ser utilizado para la evaluación de la escoliosis a través de la herramienta "PixViewer" con la misma fiabilidad que el método clásico en radiografías impresas.

Descriptores: Escoliosis; Enfermedades de la columna vertebral; Curvaturas de la columna vertebral; Intensificación de imagen radiográfica.

\section{INTRODUCTION}

Scoliosis is classically defined as a lateral deviation of the spine. ${ }^{1}$ It is known, however, that it is a three-dimensional deviation with components of lateral deviation, deviation in the sagittal plane (deviation from front to back), and rotational deviation of the vertebrae. ${ }^{2}$
During the evaluation of a patient with suspected scoliosis, a radiological assessment should be conducted using panoramic radiographs of the spine in posterior-anterior and lateral views in a standing position. This examination is critical for the follow-up of the patient and the choice of the treatment to be implemented. ${ }^{1,3,4}$ The key parameter analyzed in the radiographs is the angle of the scoliotic curve, using the most acknowledged method described by 
the North American orthopedist John Robert Cobb in 1948, apud Rigo, ${ }^{2}$ Canale and Beaty, ${ }^{5}$ Langensiepen et al., ${ }^{6}$ and Tanure et al., ${ }^{7}$ and still used today to guide clinical follow-up and the proper treatment of the pathology.

The method described by Cobb starts with the identification of the proximal and distal end vertebrae of the scoliotic curve. For this, the most proximal vertebra, the upper surface of which has the greatest slope towards the concave side of the curve, and the most distal vertebra, the lower surface of which has the greatest slope towards the concave side of the curve, are identified. A line is drawn perpendicular to the upper surface of the vertebra most proximal to the curve and another perpendicular to the lower surface of the vertebra most distal from the curve. The angle formed by the intersection of these lines is the Cobb angle..$^{5,8}$

With the advent of digital radiology, the images began to be obtained and stored using digital systems, giving rise to PACS (Picture Archiving and Communication System) ${ }^{8-10}$ With this, tools capable of measuring dimensions and angulations in the digitalized radiographs emerged, and with them, the need to confirm the reproducibility of these methods as compared to the conventional method (in printed radiographs). ${ }^{6}$

In this study, our objective was to demonstrate that measuring the angles of the scoliotic curve by means of the Cobb method can be performed reliably directly from the digitalized radiographs using PixViewer software, without the need to print the films.

\section{MATERIAL AND METHODS}

We evaluated the preoperative radiographs of 23 subjects who underwent surgical treatment for scoliosis in the Orthopedic Service of the Hospital São Lucas at PUCRS in Porto Alegre. The study was approved by the Institutional Review Board. (Opinion No 409409)

The printed radiographs were evaluated randomly and without any patient identification by an orthopedist specializing in the spine. The proximal and distal end vertebrae of the main scoliotic curve were defined in each radiograph and the Cobb angle was measured using these parameters. All the radiographs were evaluated using the same goniometer and the same number 2 pencil.

In a second step, the same digitalized exams were evaluated by the same orthopedist, also randomly and without patient identification, using the "PixViewer" tool. The proximal and distal end vertebrae of the main scoliotic curve were defined in each radiograph and the Cobb angle was measured using these parameters. The use of the contrast, brightness, and zoom functions of the software were allowed for the evaluation of the digitalized radiographs, as was the angle calculator tool.

The data were tabled using Microsoft Excel software (Table 1) and analyzed for the average variation between the measurements, standard deviation, the Student's $t$ test, and intraclass correlation using SPSS software.

\section{RESULTS}

There was no difference in the choice of the end vertebrae for the Cobb angle measurement. The average variation between the two measurement methods (conventional and digitalized radiography) was $1.48^{\circ}$, with a standard deviation of $1.73^{\circ}$. The interclass correlation coefficient (ICC) showed an index of 0.99 (CI 95\%=0.9918-0.9987), demonstrating excellent reproducibility. The Student's $t$ test did not reveal any statistically significant difference between the methods ( $p>0.2)$. A difference in the measurements of more than 5 degrees was recorded in only two of the patients. There was no difference greater than 7 degrees.

\section{DISCUSSION}

Scoliosis is a disease characterized by lateral deviations of the spine in the frontal plane associated with rotations of the vertebral bodies and it is the most common spinal deformity in children and adolescents. ${ }^{1,3,6}$ It may be asymptomatic in its mildest forms, however, when severe,
Table 1. Evaluation of the Cobb angle.

\begin{tabular}{|c|c|c|c|c|c|c|c|}
\hline \multirow{3}{*}{ Patient } & \multicolumn{7}{|c|}{ Main curve } \\
\hline & \multicolumn{2}{|c|}{$\begin{array}{l}\text { Upper end } \\
\text { vertebra }\end{array}$} & \multicolumn{2}{|c|}{$\begin{array}{l}\text { Lower end } \\
\text { vertebra }\end{array}$} & \multicolumn{3}{|c|}{ Cobb angle } \\
\hline & Film & PixViewer & Film & PixViewer & Film & PixViewer & Difference \\
\hline$A$ & $\mathrm{~T} 12$ & T12 & L3 & L3 & 50 & 49.24 & 0.76 \\
\hline B & $\mathrm{T} 10$ & $\mathrm{~T} 10$ & L3 & L3 & 60 & 62.09 & 2.09 \\
\hline C & T8 & T8 & L1 & L1 & 90 & 87.88 & 2.12 \\
\hline D & T6 & T6 & L1 & L1 & 87 & 87.98 & 0.98 \\
\hline E & T4 & $\mathrm{T} 4$ & T11 & T11 & 63 & 64.85 & 1.85 \\
\hline $\mathrm{F}$ & T12 & T12 & L3 & L3 & 40 & 40.77 & 0.77 \\
\hline G & T5 & T5 & L1 & L1 & 90 & 89.83 & 0.17 \\
\hline $\mathrm{H}$ & T12 & $\mathrm{T} 12$ & L4 & L4 & 43 & 44.13 & 1.13 \\
\hline I & T5 & T5 & L1 & L1 & 10 & 10.35 & 0.35 \\
\hline J & T1 & $\mathrm{T} 1$ & L1 & L1 & 80 & 79.93 & 0.07 \\
\hline K & T5 & T5 & T11 & T11 & 45 & 46.45 & 1.45 \\
\hline L & $\mathrm{T} 12$ & T12 & L4 & L4 & 64 & 65.61 & 1.61 \\
\hline M & T6 & T6 & T11 & T11 & 70 & 69.82 & 0.18 \\
\hline $\mathrm{N}$ & $\mathrm{T} 12$ & T12 & L4 & L4 & 27 & 26.84 & 0.16 \\
\hline $\mathrm{O}$ & T5 & T5 & T11 & T11 & 82 & 82.53 & 0.53 \\
\hline$P$ & T11 & T11 & L3 & L3 & 80 & 78.38 & 1.62 \\
\hline Q & T5 & T5 & $\mathrm{T} 12$ & T12 & 58 & 63.61 & 5.61 \\
\hline $\mathrm{R}$ & T6 & T6 & $\mathrm{T} 12$ & T12 & 100 & 99.31 & 0.69 \\
\hline$S$ & T4 & T4 & $\mathrm{T} 11$ & $\mathrm{~T} 11$ & 47 & 53.91 & 6.91 \\
\hline$T$ & T3 & T3 & $\mathrm{T} 12$ & T12 & 70 & 69.60 & 0.40 \\
\hline U & T9 & T9 & L2 & L2 & 43 & 44.64 & 1.64 \\
\hline
\end{tabular}

it can compromise the heart and lungs. ${ }^{3,4}$ In approximately $80 \%$ of cases, the factor that causes the deformity remains unknown, so it is defined as idiopathic. In the other $20 \%$, most cases are caused by deformities in the formation or segmentation of the vertebrae in utero (congenital scoliosis), due to some disease that modifies the muscle tonus (neuromuscular scoliosis), or are related to some syndrome. ${ }^{3}$ There are other less common causes for the development of scoliosis, such as vertebral fractures, spinal infection, or tumors., ${ }^{1,11}$

Radiographs play a very important role in the evaluation and monitoring of patients with scoliosis, and should be analyzed in series with the end vertebrae of the curve defined and the angle of the curve measured using the Cobb method. ${ }^{3-5}$ Although it is a simple and easily applied method, there are studies that report interobserver and intraobserver variations of from 5 to 7 degrees in the Cobb angle measurements. This should always be considered in the assessment of scoliotic curve progression. 3,5,6

Currently, an increasing number of hospitals and diagnostic imaging centers are adopting digital radiographs in place of conventional ones. ${ }^{12}$ Despite the higher cost for the initial deployment of digital technology, after one year of use, the savings in printed film begins to pay back. ${ }^{13}$ Additionally, digital radiographs offer several features: software with tools to improve the quality of the images and the measurement of angles, distances, and other parameters; ${ }^{14}$ viewing and rapid sending by means of e-mail or cellular telephones; ${ }^{15}$ easy storage, eliminating the need to print film and saving space; and less exposure to radiation. ${ }^{12}$ With the possibility of manipulating the images after they are obtained, there is less need to redo exams because of poor quality. ${ }^{16}$

In view of this new reality, it became necessary to prove that the new technology available provides information with the same safety and consistency as conventional radiographs. ${ }^{6}$ There are articles in the literature that demonstrate good intraobserver and 
interobserver reproducibility using digital radiographs to measure Cobb angles, ${ }^{8,14,17}$ however, most of them use predefined end vertebrae in their methodology.

In our study, we evaluated the radiographs of 23 patients, measuring the Cobb angle in printed film and in digitalized form using "PixViewer" software. There was no variation in the choice of the end vertebrae of the main curve. The statistical analysis showed an average variation in the Cobb angle between the two methods of $1.48 \pm 1.73^{\circ}$. This value is lower than the intraobserver variation described in the literature using the conventional printed radiograph method, which is from 5 to 7 degrees. 3,5,6 Inter- and intraobserver reproducibility analysis was not performed in this study. The ICC value of 0.99 demonstrates that the Cobb angle can be reproduced by the "PixViewer" software with the same reliability.

\section{CONCLUSION}

Our comparative study showed that the digital radiographs viewed using the "PixViewer" tool allowed the reliable and safe measurement of the Cobb angle in the evaluation of patients with scoliosis. There was no statistically significant variation in the angle values measured or change in the choice of the end vertebrae used for the measurement of the angles by the two methods in the study patients.

All the authors declare that there are no potential conflicts of interest regarding this article.

CONTRIBUTIONS OF THE AUTHORS: Each author made significant individual contributions to the development of the manuscript. EAZ, MSZ, CMDS, and AS came up with the original idea. EAZ, MSZ, RVF, and LT were the key contributors to the writing of the manuscript and the discussions. RVF, LT, and PRR conducted the bibliographical research and the data collection. CHAS and RSS supervised the study.

\section{REFERENCES}

1. Herbert S. Ortopedia eTraumatologia: princípios e prática. $4^{\mathrm{a}}$. ed. Porto Alegre: Artmed; 2009

2. Rigo M. Patient evaluation in idiopathic scoliosis: Radiographic assessment, trunk deformity and back asymmetry. Physiother Theory Pract. 2011;27(1):7-25.

3. Morrissy Raymond T, Weinstein Stuart L. Lovell and Winter's pediatric orthopaedics. 6th ed. Philadelphia: Lippincott; 2006.

4. Herkowitz HN, Garfin SR, Eismont FJ, Bell GR, Balderston RA. Rothman-Simeone the spine. 6th ed. Philadelphia: Saunders Elsevier; 2011.

5. Canale ST, Beaty JH. Campbell's operative orthopaedics. 11th ed. Philadelphia: Elsevier; 2008.

6. Langensiepen S, Semler O, Sobottke R, Fricke O, Franklin J, Schönau E, et al. Measuring procedures to determine the Cobb angle in idiopathic scoliosis: a systematic review. Eur Spine J. 2013;22(11):2360-71.

7. Tanure MC, Pinheiro AP, Oliveira AS. Reliability assessment of Cobb angle measurements using manual and digital methods. Spine J. 2010;10(9):769-74.

8. Hardesty CK, Aronson J, Aronson EA, Ranade AS, McCracken CW, NickTG, et al. Interobserver variability using a commercially available system of archived digital radiography with integrated computer-assisted measurements for scoliosis Cobb angles. J Pediatr Orthop. 2013;33(2):163-9.
9. Bansal GJ. Digital radiography. A comparison with modern conventional imaging. Postgrad Med J. 2006:82(969):425-8.

10. Cao X, Huang HK. Current status and future advances of digital radiography and PACS IEEE Eng Med Biol Mag. 2000;19(5):80-8.

11. Malfair D, Flemming AK, Dvorak MF, Munk PL, Vertinsky AT, Heran MK, et al. Radiographic evaluation of scoliosis: review. AJR Am J Roentgenol. 2010;194(Suppl 3):S8-22.

12. Buckwalter KA, Braunstein EM. Digital skeletal radiography. AJR Am J Roentgenol. 1992;158(5):1071-80.

13. Dalla Palma L, Grisi G, Cuttin R, Rimondini A. Digital vs conventional radiography: cost and revenue analysis. Eur Radiol. 1999;9(8):1682-92.

14. Srinivasalu S, Modi HN, Smehta S, Suh SW, Chen T, Murun T. Cobb angle measurement of scoliosis using computer measurement of digitally acquired radiographs-intraobserver and interobserver variability. Asian Spine J. 2008:2(2):90-3.

15. Ng KH, Rehani MM. X ray imaging goes digital. BMJ. 2006;333(7572):765-6.

16. Arenson RL. PACS: current status and cost-effectiveness. Eur Radiol. 2000;10(Suppl 3):S354-6.

17. Zhang J, Lou E, Hill DL, Raso JV, Wang Y, Le LH, et al. Computer-aided assessment of scoliosis on posteroanterior radiographs. Med Biol Eng Comput. 2010;48(2):185-95. 